\title{
DIE VERKLARING VAN DIE TIEN GEBOOIE VOLGENS DIE HEIDELBERGSE KATEGISMUS 1
}

\author{
P.J. de Bruyn \\ Departement Dogmatologiese vakke \\ Potchefstroomse Universiteit vir $\mathrm{CHO}$ \\ POTCHEFSTROOM
}

\begin{abstract}
In this article the explication of the Ten Commandments according to the Heidelberg Catechism is unalyscd. The Heidelberg Catechism indicates the following characteristics:

* Adherence to the Ten Commandments indicates gratitude.

- Thie Ten Commandnents are synecdochaic in character.

- The Ten Commandments are explicated in the contert of revelation history.

- The emphasis is placed on inner convicrion.

- The negative as well as the positive vacation of the Christian is emphasized.

- The universal significance of the Decalogie is acknowledged.

* The practical implications of the Ten Commandments are indicated.

* The authority of the Ten Commandments is considered as absolute.

- The demands of the Decalogue express a personal character.

- The Roman Caholic and Lutheran divisions of the Ten Commandments are rejected.

- Biblicism is rejected.

- Perfectionism is rejected.
\end{abstract}

\section{INLEIDING}

\subsection{Probleemstelling}

Hoe moet die Tien Gebooie verklaar en verstaan word? Dat die antwoord op hierdie vraag nie so maklik en voor die hand liggend is as wat dit lyk nie, blyk baie duidelik uit die verklarings van die wet wat volgens die Skrif self en in die loop van die geskiedenis van die kerk gegee is.

'n Voorbeeld van verkeerde verklaring van die gebooie en die skrikwekkende gevolge wat dit kan hê, is die uitspraak van die Jode tydens die verhoor van Jesus Christus. Hulle het aan Pilatus gesê: "Ons het 'n wet, en volgens dié wet moet hy dood, omdat hy hom as die Seun van God voorgedoen het" (Joh. 19:7).

\footnotetext{
'Hierdic artikel vorm decl van die reeks artikels oor dic belydenis en dic belydenisskrifte. Kyk ook In die Skrifig, 25(1)1991.
} 
Omdat die Jode die derde gebod losgemaak het van die profetiese getuienis van die Ou Testament oor Christus, het hulle Christus, wat die wet van God volmaak onderhou het, as wetsoortreder laat kruisig. (Vgl. Bouma, 1950:170.) Abma (1980?:19) noem hierdie gebruik van die wet "een tragisch misverstand van de allerergste soort".

Hoe belangrik dit is dat die gebooie reg verklaar moet word, blyk verder daaruit dat Christus self ' $n$ duideliker verklaring van onder andere die vyfde, sesde en sewende gebod gegee het (Mark. 7:10-13; Matt. 5:21-22, 27-28).

Die uitwerking van 'n bepaalde verklaring van die Tien Gebooie blyk ook onder andere duidelik uit die Roomse Kerk se praktyk. Volgens hulle verklaring van die tweede gebod word slegs die aanbidding van beelde verbied, maar nie die verering daarvan nie (Douma, 1985:84). Die resultaat daarvan kan gesien word in die talle beelde wat in Roomse kerke gevind word.

In die lig hiervan kan gevra word: hoe word die Tien Gebooie deur die Heidelbergse Kategismus ${ }^{2}$ verklaar? Is dit 'n verklaring wat reg laat geskied aan die oorspronklike bedoeling van God daarmee? Wat hierdie saak so belangrik maak, is die feit dat die Tien Gebooie nie maar net 'n aantal reëls is nie, maar dat die wese van God daarin geopenbaar word. (Vgl. Jes. 1:2-15; Jer. 2:3-13.)

\subsection{Aktualiteit}

In die jongste tyd is daar verklarings van die Tien Gebooie gegee wat verskil van dié wat tradisioneel veral in reformatoriese kerke gegee is. So beweer Kuitert (1970:85) dat die gebooie in die Bybel aan die mens slegs informasie gee oor God se bedoeling met die mens en die wêreld, soos dié bedoeling in 'n bepaalde tyd verstaan en gehoorsaam is. Daarom beskou hy die gebooie slegs as paradigmas en voorbeelde.

Hierdie siening het neerslag gevind in die invloedryke publikasie van die Gereformeerde Kerken Nederland (1981): God met ons. Verder kan die uitwerking van Kuitert se siening ook duidelik gesien word by Pronk (1989:251) wat onder Kuitert gepromoveer het en wat, ondanks die Bybelse verbod en veroordeling van homoseksualiteit, verklaar dat dié verbod nie op die hedendaagse mens van toepassing is nie. In sy hele studie word die sewende gebod en die implikasie daarvan nie eers in behandeling geneem nie. Dit geld ook van Pretorius (1990) se verdediging van homoseksualiteit.

\footnotetext{
${ }^{2}$ Voortaan afgekort as HK.
} 
Uit ander oorde is daar Fletcher (1967:134) en Kroeze (1970:138) wat voorhuwelikse geslagsgemeenskap nie beskou as 'n handeling wat deur die sewende gebod verbied word nie, terwyl dit in die verlede wel as 'n oortreding van die sewende gebod gesien is (Geesink, 1931:407).

\subsection{Noodsaaklikheid}

Uit wat in die vorige punte gesê is, is dit duidelik dat die regte verstaan van die Tien Gebooie vir die Christen absoluut noodsaaklik is. Tog is dit opvallend dat daar in talle - ook resente - verklarings van die Tien Gebooie weinig aandag gegee is aan die spesifieke kenmerke daarvan wat by die verklaring in ag geneem moet word. Meesal word volstaan met enkele kort en bondige opmerkings daaroor (Geesink, 1931:223235; Douma, 1985:20-24; Buys, 1988:6).

In die lig hiervan en in die lig van die groot rol wat die HK in die reformatoriese kerke speel, is dit nodig om vas te stel wat die kenmerke of karaktertrekke van die Tien Gebooie volgens die HK se verklaring daarvan is.

Slegs die belangrikste kenmerke word hier behandel.

\section{DIE KENMERKE}

\subsection{Die aanduiding van die Tien Gebooie as reēl van dankbaarheid}

Een van die mees opvallende kenmerke van die HK se verklaring van die Tien Gebooie is dat hierdie gebooie aan die Christen voorgehou word as reël ván dankbaarheid. (Vgl. Büsser, 1963:163-165.) Dit blyk duidelik uit die plek van die Tien Gebooie in die HK as geheel.

Die HK begin deur aan te dui wat die gelowige se enigste troos in lewe en in sterwe is (vr. en antw. 1). In aansluiting daarby word dan die vraag gestel wat die gelowige moet weet om te kan deel in dié troos. Daarop word geantwoord: "Drie dinge: Ten eerste hoe groot my sonde en ellende is; ten tweede hoe ek van al my sonde en ellende verlos word; en ten derde hoe ek God vir so 'n verlossing dankbaar moet wees" (antw. 2). Op hierdie wyse word die HK in die bekende drie dele ingedeel.

Die wet van God kom op verskeie plekke in die HK ter sprake omdat dit meer as een funksie het. In Sondag 2 word dit samevattend weergegee as God se dubbele liefdes- 
gebod. Hier, en trouens in die hele eerste deel van die HK, funksioneer dit as kenbron van die mens se ellende. Van hierdie ellende, wat die gevolg is van die mens se wetsoortreding, het Christus die mens kom verlos. Dit word in die tweede deel van die HK beklemtoon. So word in antwoord 60 gesê "dat al kla my gewete aan dat ek teen al die gebooie van God swaar gesondig het ... God nogtans aan my sonder enige verdienste aan my kant uit loutere genade die volkome voldoening, geregtigheid en heiligheid van Christus skenk".

Dan volg die derde deel van die HK wat handel oor die dankbaarheid. Daar word die wet dan in die vorm van die Tien Gebooie behandel. Die onderhouding daarvan moet dus deel vorm van die dankbaarheid wat die mens teenoor God moet betoon vir sy verlossingswerk in en deur Jesus Christus.

In hierdie verband is dit opvallend dat daar in die weergawe van die Tien Gebooie in die HK nie begin word met die eerste gebod nie, maar met die inleidende woorde tot die Tien Gebooie: "Ek is die Here jou God wat jou uit Egipteland, uit die slawehuis, uitgelei het."

Dat hierdie woorde ook in die HK opgeneem is, is van groot betekenis. Hierdie woorde dui immers die groot indikatief van God aan waaruit sy imperatief aan die mens (die verskillende gebooie) voortvloei. Omdat God Israel uit Egipte bevry het, moet hulle uit dankbaarheid die Dekaloog onderhou (Haitjema, 1962:227), of om dit Nuwe-Testamenties te formuleer: omdat God in Christus sy volk uit die Egipte van slawerny van die sonde (Op. 11:8) verlos het, moet hulle uit dankbaarheid doen wat $\mathrm{Hy}$ hulle beveel (De Bruyn, 1973:32-34). Hoewel die inleidende woorde die Tien Gebooie ook binne die kader van die verbond plaas en die verskillende gebooie derhalwe as verbondseise kwalifiseer (De Graaf, 1954:27-31), val die nadruk in die HK tog baie sterk op die betekenis wat dit as reël van dankbaarheid het, sonder dat die betekenis as verbondseise enigsins verminder word.

Die HK gee wel nie expressis verbis so 'n verklaring van die inleidende woorde van die Wet van die Here nie. In 'n sekere sin is dit egter ook nie nodig nie omdat die hele tweede gedeelte van die HK wat oor die verlossing handel, eintlik 'n verklaring van die inleidende woorde is en daarin saamgetrek word. (Vgl. Veldkamp, 1955?:142.)

Op grond van die plek wat die HK aan die onderhouding van die wet gee, word duidelik standpunt ingeneem teen die Roomse Kerk met sy siening van die verdienstelikheid van goeie werke (Overduin, 1961:26-29). Goeie werke is volgens die HK wel noodsaaklik (antww. 62-64, 86-91), maar nie as deel van die verkryging van verlossing 
nie maar as lewe van dankbaarheid teenoor God wat sy uitverkorenes reeds in en deur Jesus Christus verlos het (Holwerda, 1955:127-129).

As 'n mens die inleidende woorde van die Tien Gebooie in Nuwe-Testamentiese perspektief sien, en in die lig daarvan na die gebooie self kyk, word dit duidelik dat die gebooie vir die gelowige nie 'n dwangkarakter behoort te hê nie (Haitjema, 1962:227); inteendeel, die onderhouding daarvan behoort vir hom 'n dankbare vreugde te wees (Van Minnen, 1967?:51). En wie die Tien Gebooie met hierdie gesindheid gehoorsaam, sal ook verstaan wat Johannes bedoel as hy sê: "Sy gebooie is nie moeilik om te gehoorsaam nie" (1 Joh. 5:3).

\subsection{Die erkenning van die sinekdogeïese karakter van die Tien Gebooie}

By die deurlees van die verklarings wat die HK van die Tien Gebooie gee, val dit 'n mens op dat by elke gebod aan baie meer sake aandag gegee word as wat in die betrokke gebooie genoem word. Dit is egter duidelik dat die verskillende sake wat deur die HK aangesny word, sonder enige twyfel verband hou met die saak wat in die betrokke gebod genoem word.

Tog ontstaan die vraag of Ursinus en die sinodale kommissie (Schulze, 1991:41) die reg gehad het om die implikasie van elke gebod so uit te brei. Hierop is die antwoord dat hulle wel die reg gehad het om dit te doen omdat hulle begryp het dat die verskillende gebooie in die vorm van sinekdogeë gegee is (Douma, 1985:23).

Die sinekdogee is 'n stylfiguur waarby 'n geheel deur 'n deel aangedui word (HAT). 'n Deel word genoem, maar die geheel word bedoel. 'n Duidelike voorbeeld van' $n$ sinekdogee vind 'n mens in die vierde bede van die Onse Vader. Daarin word letterlik vir "daaglikse brood" gebid, maar die bedoeling daarvan is om van God "alles wat vir die liggaam nodig is" te vra (antw. 125). En dit sluit behalwe brood ook ander soorte kos in, en verder ook klere en alle ander noodsaaklike lewensmiddele.

Die opstellers van die HK het net soos Calvyn, die Tien Gebooie as sinekdogeë beskou. In sy Institusie sê Calvyn (1986:2.8.8, p. 507) immers: "Ons (moet) daarop let dat daar altyd meer is in dit wat die wet gebied en dit wat dit verbied as wat die woorde voorgee ... In feitlik al die gebooie is daar in elk geval soveel duidelike sinekdogee dat iemand wat die betekenis van die wet tot die grense van die woorde daarvan sou wil beperk, bespot sou word." (Vgl. Geesink, 1931:235.) 
Die reg om die gebooie as sinekdogeë te beskou, word ook in die Skrif gevind. Christus self toon byvoorbeeld in Matteus 5:21-22 en 27-28 dat die eise van die gebooie baie verder strek as bloot die letterlike woorde daarvan. Daarom het die opstellers van die HK die Tien Gebooie so verklaar dat hulle vanuit die deel wat genoem word, die groter geheel van God se eis oor die betrokke saak aangedui het.

In die eerste gebod word afgodery verbied, maar in die HK word ook "towery, waarsêery, bygeloof, aanroeping van heiliges en ander skepsels" ter sprake gebring (antw. 94). By die tweede gebod word die verbod op die maak van beelde van God uitgebrei na enige vorm van verering van God wat anders is as wat $\mathrm{Hy}$ in sy Woord beveel (antw. 96). By die derde gebod oor die misbruik van die Naam van die Here word ook eedswering behandel (antww. 99,101,102). Die vierde gebod verduidelik die woord rus in die lig van die Nuwe Testament (vgl. punt 2.3) en so kom die Woordbediening, eredienste, die daaglikse rus (nalaat) van alle bose werke en die werking van die Heilige Gees ter sprake (antw. 103). Die vyfde gebod word nie net op die verhouding van kinders tot ouers toegepas nie maar ook op die verhouding van alle gesagsonderdane tot gesagsdraers (antw. 104). By die sesde gebod word van doodslag na ontering, haat, belediging, woede, wraaklus, ensovoorts uitgebrei en liefde, geduld, vriendelikheid, ensovoorts word daarteenoor gestel (antww. 105-107). By die sewende gebod word getoon dat God daarmee baie meer verbied "as net egbreuk en dergelike skandes" (antw. 109). By die agtste gebod oor diefstal word die mens se hele verhouding tot sy eie en ander mense se aardse besittings ter sprake gebring en sy positiewe roeping in die verband word ook aangedui (antw. 110-111). Die verklaring van die negende gebod trek die lyn deur van valse getuienis na die verdraaiing van woorde, kwaadspreek, laster, onverhoord veroordeel en die roeping om die medemens se eer en goeie naam te beskerm (antw. 112). In die tiende gebod, soos dit in die Skrif weergegee word, word enkele voorbeelde genoem van besittings van die naaste wat nie begeer mag word nie, maar die HK brei dit uit na "die geringste begeerte of gedagte teen enige gebod van God" (antw. 113).

Hieruit is dit duidelik in hoe 'n mate die opstellers van die HK die verskillende gebooie van die Dekaloog as sinekdogeë beskou het en dit ook as sodanig verklaar het. En dit is vir die toepassing van die Tien Gebooie deur die eeue heen van geweldige belang. Trouens, in die loop van die geskiedenis het die mens telkens met nuwe verskynsels op etiese gebied te doen gekry, byvoorbeeld geboortebeperking, aborsie, eutanasie, orgaanoorplantings, eksperimente op embrio's, surrogaatmoederskap, omgewingshesoedeling, ensovoorts. Vir hierdie verskynsels of praktyke hoef daar geen nuwe gebooie gemaak te word of byvoegings by die Tien Gebooie oorweeg te word nie. Juis die feit dat die gebooie in die vorm van sinekdogeë gegee is en as sodanig deur die 
HK verklaar word, toon duidelik aan dat etiese vraagstukke nie net beoordeel moet word in die lig van die deel wat genoem word nie maar in die lig van die geheel wat bedoel word. En dit beteken dat selfs die heel modernste verskynsels of praktyke op etiese gebied beskou kan word as die groter geheel waarop die verskillende gebooie van toepassing is.

\subsection{Die openbaringshistoriese karakter van die verklaring van die Tien Gebooie}

Dat die HK die Tien Gebooie openbaringshistories verklaar het, sien 'n mens seker nêrens duideliker as in die verklaring van die vierde gebod nie.

As 'n mens die vierde gebod in die Bybel lees en jy plaas die verklaring wat die $\mathrm{HK}$ (Sondag 38) daarvan gee daar langsaan, lyk dit met die eerste oogopslag of die HK dinge daaruit aflei wat nooit daarmee bedoel was nie. Die hoofsaak van die vierde gebod is immers dat die mens op die Sabbat sy gewone, daaglikse werk moet nalaat; hy moet daarvan rus. Daarteenoor kom die HK en sê dat dit in die vierde gebod veral gaan om die verkondiging van die Woord, of, soos dit eintlik bedoel is, die verkondiging van Jesus Christus as Verlosser van sondes. Die vierde gebod en die verklaring wat daarvan gegee word, is dus skynbaar met mekaar in stryd.

As iemand die vierde gebod bloot in sy Ou-Testamentiese vorm wil verstaan, sal hy hier beslis op 'n teenstrydigheid stuit. Waarom? Omdat die vierde gebod in die HK openbaringshistories verklaar is en ook so verstaan moet word.

Die rus waarvan die vierde gebod in die Ou Testament praat, het meer beteken as net die nalaat van werk op die sewende dag; dit was ook 'n heenwysing na die ware, innerlike rus wat Christus deur sy soenverdienste vir sy volk sou bewerk (Heb. 4:3-11). Dié rus bestaan veral daarin dat die gelowige kan weet dat hy deur Christus van sy sonde verlos is. En aangesien dit juis die sonde is wat die oorsaak van die mens se onrus is, of, soos die Nagmaalsformulier (1988:622) die sonde noem, "die oorsaak van ons ewige honger en kommer", beteken die verlossing van sonde vir die gelowige dat hy daardeur die ware. innerlike rus vind. Vir hom is Christus die groot rusbringer wat gekom het om aan vermoeides en belastes rus te gee (Matt. 11:28).

Die vierde gebod is deur Christus vervul en daarom het dit in sy Ou-Testamentiese vorm ook verval. En as Nuwe-Testamentiese gelowiges nou hierdie gebod wil verstaan, moet hulle dit verstaan vanuit die volbragte werk van Jesus Christus, vanuit die vervulling van hierdie gebod deur Christus. Hulle moet dit verstaan in die lig van die feit 
dat Christus self die diepste sin van die vierde gebod is omdat Hy die ware rusbringer vir sondige mense geword het. Daarom moet Hy as sodanig aan die wêreld en in die besonder aan sy kerk verkondig word. Daarom ook moet eredienste op Sondae gehou word en moet die Christen ook alle bose werke wat die rus wat hy in Christus verkry het, kan versteur, elke dag van die week nalaat.

So verstaan die HK die vierde gebod. Daarom gee dit ook nie 'n verduideliking van die vierde gebod in sy Ou-Testamentiese vorm nie, maar dit gee 'n uiteensetting van die betekenis van hierdie gebod soos dit en nadat dit deur Christus vervul is toe Hy gely en gesterf het om sy uitverkore kinders te verlos van hulle sondes en aan hulle ware rus te gee (Heb. 4:3-11).

Vanselfsprekend is dit nie net die vierde gebod wat openbaringshistories verklaar is nie, maar almal. In die lig van die Nuwe Testament kan dit trouens nie anders verklaar word nie. Die vierde gebod is slegs behandel omdat dit daarin die duidelikste tot openbaring kom.

\subsection{Die beklemtoning van die innerlike gesindheid}

Wat in die verklaring van die Tien Gebooie deur die HK baie opvallend is, is die nadruk wat gelê word op die gesindheid van die hart (Douma, 1985:23). Hoewel dit in die verklarings van sommige gebooie duideliker aangedui word as in ander, is dit tog in die verklaring van elke gebod te vinde soos blyk uit die volgende:

By die eerste gebod word gesê:

Ek moet die enige ware God reg leer ken, Hom alleen vertrou, my slegs aan Hom met alle nederigheid en geduld onderwerp en van Hom alleen alle goeie dinge verwag. Ek moet Hom met my hcle hart licfhê, vrces en eer (antw. 94).

Oënskynlik word die innerlike gesindheid in die verklaring van die tweede gebod nie met soveel woorde aangedui nie. Tog is dit baie duidelik inbegrepe in die woorde "... en Hom op geen ander manier vereer as wat Hy in sy Woord beveel het nie" (antw. 96). Dat die innerlike gesindheid hier sterk beklemtoon word, blyk veral duidelik uit die Skrifgedeeltes waarna by die aangehaalde woorde verwys word (1 Sam. 15:23; Deut. 12:30 en Matt. 15:9). In 1 Samuel 15:23 is daar sprake van "weerspannigheid" en "eiesinnigheid" in die diens van die Here, met ander woorde dat die mens in sy eie sondige hart besluit hoe God gedien moet word en Hom nie deur God laat voorskryf hoe Hy gedien wil word nie. En dit is tog die essensie van die tweede gebod, naamlik dat die mens verbied word om God op 'n eiewillige wyse te dien - met of sonder beelde. (Vgl. Ursinus, 1886:208.) 
By die derde gebod word die innerlike gesindheid beklemtoon met dié woorde: "Ons moet die Naam van God nie anders as met vrees en eerbied gebruik nie" (antw. 99).

In die verklaring van die vierde gebod word die innerlike gesindheid kort en kragtig aangedui as gesê word: "Ek moet ... die Here deur sy Gees in my laat werk" (antw. 103).

Die verklaring van die vyfde gebod praat van die eer, liefde, trou en geduld wat aan ouers en ander gesagsdraers betoon moet word (antw. 104).

By die sesde gebod word baie nadruk op die innerlike gesindheid gelê as gesê word dat die gelowige sy naaste nie eers met sy gedagtes "mag onteer, haat, beledig of Joodmaak, nie" (antw. 105) en "terwyl God afguns, haat en woede verbied, gebied Hy dat ons ons naaste moet liefhê soos onsself. Ons moet teenoor hom geduldig. vredeliewend, sagmoedig, barmhartig en vriendelik wees" (antw. 107).

As die eis van die sewende gebod verduidelik word, word gesê dat die Christen alle onkuisheid "hartgrondig moet haat" (antw. 108). God verbied immers ook "alle onkuise ... gedagtes, luste en alles wat 'n mens daartoe kan verlei" (antw. 109). Die verwysing na onder andere Matteus 5:27 en 28 ter stawing van laasgenoemde uitspraak, toon baie duidelik watter nadruk daar op grond van die Skrif op die innerlike gesindheid gelê word.

Die innerlike gesindheid van die mens kom in die verklaring van die agtste gebod onmiskenbaar na vore deur die gebruik van woorde soos "skelmstreke en liste", en verder "gierigheid" en "verkwisting" (antw. 110). Die innerlike gesindheid kom veral aan die lig as daar in die positiewe gedeelte gesê word dat God wil hê dat "ek ... my naaste ... so moet behandel soos ek wil hê dat die mense my moet behandel" (antw. 111).

Hoe duidelik word die innerlike gesindheid nie ook in die negende gebod beklemtoon nie! Daarin word immers duidelik gestel dat die kind van God nie slegs die waarheid moet praat nie, maar die waarheid moet liefhê. Daarby moet hy opreg wees in alles wat hy sê en bely (antw. 112).

Asof die innerlike gesindheid nog nie voldoende in die verklaring van die ander gebooie beklemtoon is nie, word dit in die verklaring van die tiende gebod opnuut gedoen as daar in 'n sekere sin terugskouend op al die voorafgaande gebooie gesê word: "Selfs die geringste begeerte of gedagte teen enige gebod van God mag nooit in ons hart opkom nie. Ons moet altyd en hartgrondig vyande van alle sonde wees en 'n 
begeerte tot alle geregtigheid hê" (antw. 113). Die feit dat die woord "begeerte" twee maal in hierdie antwoord gebruik word, eers in 'n ongunstige en dan in 'n gunstige sin, toon dat 'n begeerte as sodanig nie verkeerd is nie, maar dat die reg of verkeerd van 'n begeerte van die gesindheid in die hart van die mens afhang, want dit bepaal die karakter van die begeerte.

Die sterk nadruk wat die HK by die verklaring van die Tien Gebooie op die regte innerlike gesindheid lê, is heeltemal in ooreenstemming met sowel die Ou Testament as die Nuwe Testament (Ps. 51:12; Spr. 4:23; 23:26; Jes. 1:11-17; 29:13; Joël 2:12-14; Miga 5:7-8; Matt. 5:27,28; 15:7,8; 22:35-40; 23:1-39, ens.). Dwarsdeur die Skrif word daar immers geweldige nadruk gelê op die regte gesindheid van die hart in die diens van die Here (vgl. Wielenga, 1947:737-738). Daarteenoor word uiterlike godsdienstige handelinge sonder die regte gesindheid van die hart ten sterkste deur die Here afgewys en veroordeel.

\subsection{Die beklemtoning van die negatiewe en positiewe roeping van die Christen}

Van die tien gebooie is agt negatief geformuleer, een (die vierde) gedeeltelik negatief en gedeeltelik positief en een (die vyfde) positief. Dit val 'n mens egter op dat die HK in sy verklaring van die negatief-geformuleerde gebooie die positiewe eis wat daaruit voortvloei, baie sterk beklemtoon. By sewe van hierdie gebooie, naamlik die eerste, die derde, die sesde, die sewende, die agtste, die negende en die tiende gebod word die positiewe eis wat elkeen van hulle behels eksplisiet aangedui.

Die verklaring van die tweede gebod is hoofsaaklik negatief. Tog word die positiewe eis by implikasie in antwoord 96 aan die gelowige voorgehou, naamlik dat hy God slegs moet vereer op die wyse wat Hy in sy Woord beveel. Daarom word daar in antwoord 98 ook positief baie nadruk gelê op die belangrikheid van die onderrig van die Christene deur die lewende verkondiging van God se Woord.

Wat ' $n$ mens by die positiewe eis van die tweede gebod mis, is die roeping van die gelowige om self die beeld van God steeds duideliker te vertoon. Teenoor die afwysing van beeldediens sou dit op grond van die Skrif sinvol as deel van die positiewe eis beklemtoon kon word. Billikheidshalwe moet egter genoem word dat hierdie aspek wel baie duidelik in antwoord 115 beklemtoon word.

Die verklarings van die vierde en vyfde gebod is feitlik in hulle geheel positief. In antwoord 103 het slegs die sin "ten tweede moet ek elke dag van my lewe van my bose 
werke rus ..." 'n negatiewe strekking. In die verklaring van die vyfde gebod sou 'n mens aan die woorde "ook moet ek met hulle gebreke geduld hê ..." 'n negatiewe konnotasie kon heg in die sin van 'nie oor hulle gebreke in opstand kom nie'. Dit hoef egter nie noodwendig so verklaar te word nie en kan ook vertolk word as 'in liefde verdra.'

Uit die voorgaande is dit duidelik dat, terwyl dia Tien Gebooie self hoofsaaklik negatief geformuleer is, die HK dit so verklaar dat sowel die negatiewe as die positiewe aspekte daarvan sterk bekiemtoon word. (Vgl. Büsser, 1963:166-167.)

Die vraag kan egter ontstaan: Het die opstellers van die HK reg gehandel deur die Tien Gebooie so te verklaar? Ilierop kan beslis bevestigend geantwoord word - om verskillende redes.

Eerstens vloei dit voort uit die sinekdogeiese aard van die Tien Gebooie wat in punt 2.2 behandel is. Die geheel wat bedoel word met die deel wat genoem word, sluit beslis die positiewe roeping van die gelowige in. Die Bybel as geheel toon immers duidelik dat God nie tevrede is met 'n negatiewe gesindheid waarvolgens volstaan word daarmee dat sekere dinge nie gedoen word nie; inteendeel, Hy eis 'n positiewe toewyding aan sy diens wat in 'n vrugbare lewe tot openbaring kom (Luk. 13:6-9; Joh. 15:1-8: Gal. 5:22).

Tweedens is die Tien Gebooie in werklikheid niks anders nie as 'n duidelike konkretisering van die eis van liefde tot God en liefde tot die naaste. Dit blyk baie duidelik uit Romeine 13:8-9 waar Paulus skryf: "Julle moet niemand iets verskuldig wees nie, behalwe om mekaar lief te hè. Wie sy medemens liefhet, voer die hele wet van God uit. Al die gebooie: 'Jy mag nie egbreuk pleeg nie, jy mag nie moord pleeg nie, jy mag nie steel nie, jy mag nie begeer nie' of watter ander gebod daar ook al is, word immers in hierdie een gebod saamgevat: 'Jy moet jou naaste liefhê soos jouself." In antwoord 93, wat in 'n sekere sin die tema is vir die behandeling van die Tien Gebooie van vraag en antwoord 94 af, word inhoudelik en deur Skrifverwysings ook na die dubbele liefdesgebod verwys. En aangesien die egte betoning van die liefde nooit bloot uit 'n negatiewe optrede bestaan nie, maar juis in positiewe dade tot openbaring kom, is dit ook te verstane dat daar in die verklaring van die Tien Gebooie deur die HK baie aandag aan die positiewe implikasies van die verskillende gebooie gegee is (vgl. Van Andel, 1935:197). Bowendien, in antwoord 91 is goeie werke aangedui as werke wat "volgens die wet van God tot sy eer gedoen word". Van sulke goeie werke tot eer van God sal weinig tereg kom as daar slegs by 'n negatiewe optrede - 'n niedoen-nie - volstaan word. 


\subsection{Die erkenning van die universele betekenis van die Dekaloog}

As 'n mens die Tien Gebooie deurlees, kan die tipies Israelitiese karaktertrekke nie misgekyk word nie. Die inleidende woorde verwys na Israel se verlossing uit Egipteland. In die vierde en tiende gebod kry 'n mens duidelike verwysings na vee in die algemeen en beeste en donkies in die besonder. So sluit dit aan by die nomadiese bestaan van Israel. Op tipies Oosterse wyse word die vrou as besitting van die man genoem (Buys, 1989:6). In die vyfde gebod word na die beloofde land verwys en dit het vir Israel 'n baie spesifieke betekenis gehad.

Van hierdie tipies Israelitiese karaktertrekke word in die verklaring van die HK niks gevind nie; inteendeel, dit word so verklaar dat dit 'n universele betekenis kry, met ander woorde dat dit geld vir Christene uit alle volke van die wêreld. Daarby word dit nie net toegepas op Christene se gedrag onderling nie - dit wel primêr (Gal. 6:10) maar ook op hulle gedrag teenoor mense wat nie Christene is nie. Die wyse waarop die Tien Gebooie in die nuwe Testament gehanteer word (Matt. 19:18-19; Luk. 10:2627; Rom. 12:20; 13:8-9) toon sonder twyfel dat die opstellers van die HK reg opgetree het deur die Dekaloog so te verklaar.

Die universele karakter van die Tien Gebooie volgens die verklaring van die HK kom onder andere duidelik na vore in die gebruik van die woord naaste. Dit word nie minder as ses keer nie in die verklaring van die verskillende gebooie gebruik (antww. $101,105,107,110,111,112)$. In aansluiting by die gebruik van dié woord in die negende en tiende gebod, word dit aangewend om die Christen se gesindheid en gedrag teenoor sy medemens aan te dui.

Dat die woord naaste in hierdie herhaalde gebruik daarvan in die $\mathrm{HK}$ in die universele betekenis van die woord bedoel word, word vir 'n mens duidelik as in gedagte gehou word dat die Jode selfs tydens Christus se omwandeling op aarde in stryd met die uitdruklike voorskrifte van die Here (Lev. 19:33, ens.), slegs hulle mede-Jode as hulle naaste beskou het (Greijdanus, 1955:279-280). Daarteenoor het Christus onder andere in die gelykenis van die barmhartige Samaritaan (Luk. 10:25-37) aangetoon dat die Christen se naaste enige mens is met wie hy in aanraking kom. Uit die verband waarin die woord nacste in die HK se verklaring van die Tien Gebooie gebruik word, is dit duidelik dat dit gebruik word in die lig van Christus se onderrig oor wie die gelowige se naaste is. Dit blyk veral baie duidelik uit antwoord 112, waar die woord niemand drie maal kort na mekaar in dieselfde sin gebruik word: niemand mag deur valse getuienis, ensovoorts benadeel word nie omdat almal die Christen se naaste is wie se eer en goeie naam hy moet verdedig en bevorder. 


\subsection{Die praktiese karakter van die HK se verklaring}

In sy verklaring van die Tien Gebooie bly die HK nie by teorieë en abstraksies nie, maar kom dit te staan midde in die konkrete lewe van elke dag. So maak die HK melding van towery, waarsêery en bygeloof (eerste gebod); van die maak van beelde en 'n diens aan God op ' $n$ ander manier as wat Hy beveel (tweede gebod); van die lastering van God se Naam en eedswering (derde gebod); van eredienste op Sondae met prediking, gebede, sakramcnte en offergawes (vierde gebod); van gehoorsaamheid aan ouers en geduld met hulle gebreke (vyfde gebod); van moord, selfmoord, beledigings en wraaksug (sesde gebod); van onkuise dade, gebare, woorde en gedagtes (sewende gebod); van valse gewigte, lengtemaat en inhoudsmaat (agtste gebod); van die verdraaiing van woorde, kwaadstokers en die beskerming van die naaste se eer en goeie naam (negende gebod) en van die geringste gedagte of begeerte teen enige gebod van God (tiende gebod).

Vir die mens wat die HK lees, behoort dit dus duidelik te wees dat die eise wat God in die Tien Gebooie stel, op die konkrete werklikheid betrekking het.

\subsection{Die erkenning van die absoluutheid van die eise in die Tien Gebooie}

Die Tien Gebooie is geformuleer in die vorm van absolute, totalitêre eise. So word in die eerste gebod van die mens geëis om God alleen te dien en eksklusief net aan Hom as die enigste God onderworpe te wees. Naas God mag daar vir die mens "geen ander gode" wees nie (Eks. 20:3). In die tweede gebod eis God van die mens om Hom op geen ander wyse te vereer as wat $\mathrm{Hy}$ in sy Woord beveel nie. In die derde gebod verbied $\mathrm{Hy}$ die mens om ooit sy Naam ydellik te gebruik, ensovoorts (vgl. Van den Berg, 1967?:31).

In die HK word hierdie absolute aard van God se eis in die gebooie op duidelike wyse vertolk. Sonder om na enige uitsonderings te verwys, word in die HK aangetoon wat 'n mens nie mag doen nie én wat hy wel moet doen.

Vanweë die gebrokenheid waarin die lewe van die mens weens die sonde vasgevang is, is hy soms genoodsaak om die gebooie te oortree, byvoorbeeld as hy ter beskerming van homself en/of sy dierbares gedwing word om 'n vyand dood te maak. Die Skrif self getuig ook daarvan dat daar soms situasies is warin die oortreding van die gebooie nie as skuld teen iemand gehou mag word nie, byvoorbeeld as 'n persoon 'n skaap wat op die Sabbat in 'n sloot val, op dieselfde dag uithaal (Matt. 12:10-12). 
Van dergelike uitsonderings word in die HK geen melding gemaak nie. Die redes waarom dit nie gedoen word nie, is waarskynlik die volgende: Eerstens word daar in die Tien Gebooie self geen uitsonderings gemaak nie; tweedens word God se wil in die vorm van absolute eise aan die mens voorgehou om te toon dat, al is die oortreding van God se gebooie in 'n sondige wêreld soms onvermydelik, soos by die botsing van pligte, dit desondanks steeds 'n oortreding van God se gebooie bly (Buys, 1976:9). Daarom moet die betrokke persoon hom in elke dergelike situasie voor God verootmoedig.

\subsection{Die persoonlike aard van die eise in die Tien Gebooie}

Die Tien Gebooie het 'n baie persoonlike aard. Dit blyk uit die gebruik van die tweede persoon enkelvoud: Jy. Die uitdrukking: "Jy mag nie..." kom (soms enigsins gewysig) elf keer in die Tien Gebooie voor. Op hierdie wyse word elke individu persoonlik aangespreek. Elke individu moet weet dat hy persoonlik voor God verantwoordelik is om hierdie gebooie te gehoorsaam.

Hierdie persoonlike gerigtheid van die Tien Gebooie is 'n baie belangrike saak. 'n Mens kan immers nie van ander verwag om die gebooie te gehoorsaam as jy dit nie self doen nie. Daarom is elke vorm van sosiale etiek (in die huwelik, gesin, kerk, arbeid, volk, staat, ens.) tot mislukking gedoem as elke mens nie bereid is om sy persoonlike verantwoordelikheid na te kom nie. Net soos wat 'n mens op die oordeelsdag persoonlik geoordeel sal word (2 Kor. 5:10), so word hy ook persoonlik deur die wet aangespreek (Douma, 1985:20).

In Eksodus 23:2 sê die Here: "Jy mag nie agter die meerderheid aan doen wat verkeerd is nie." Die gelowige mag hom dus nie sonder meer deur die meerderheid laat lei nie omdat hy persoonlik deur God aangespreek word en persoonlik voor God vir sy handel en wandel verantwoordelik is.

In ooreenstemming met die hele wyse van behandeling van sake in die vorm van vraag en antwoord, is hierdie $j y$, ook by die verklaring van die Tien Gebooie in die HK, van die tweede persoon enkelvoud na die eerste persoon enkelvoud en meervoud ( $e k$, ans) verander. Daardeur het niks van die krag van God se $j y$ verlore gegaan nie, maar toon dit juis hoe die gelowige in persoonlike verantwoordelikheid op die spreke van God moet antwoord. 


\subsection{Die afwysing van die Roomse en lutherse verdeling van die gebooie}

Die Roomse Kerk en die Lutherse Kerk het die eerste en tweede gebod tot een gebod saamgevoeg. Om weer by die getal tien uit te $\mathrm{kom}$, het hulle die tiende gebod in twee verdeel. Volgens die Roomse Kerk lui die negende gebod: "Jy mag nie iemand anders se vrou begeer nie" (Deut. 5:21a). Die res van Deuteronomium 5:21 is dan die tiende gebod. Volgens die Lutherse Kerk lui die negende gebod: "Jy mag nie iemand anders se huis begeer nie" (Eks. 20:17a). Dic res van Eksodus 20:17 is volgens hulle die tiende gebod. Die Jode en die Grieks-Ortodokse Kerk het dieselfde indeling as die reformatoriese kerke (Douma, 1987:125-127).

Die HK wys in sy verklaring die indeling van die Roomse en Lutherse Kerk af. Deur dit te doen, kom die eerste en die tweede gebod tot hulle reg. Daardeur word dit duidelik dat die eerste gebod wil sê dat die regle God (en geen ander nie) gedien moet word, terwyl die tweede gebod wil sê dat die regte God op die regte wyse (en nie op 'n eiewillige wyse nie) gedien moet word. As hierdie twee gebooie tot een saamgevoeg word, kan die sake waaroor dit eintlik in elkeen van hulle gaan, met mekaar verstrengel raak sodat nie een van hulle behoorlik tot sy reg kom nie (vgl. Ursinus, 1886:208).

Deur die tiende gebod as 'n eenheid te behou, word die verkeerde indruk weggeneem dat die sondige begeerte na die naaste se vrou (Roomse Kerk) of huis (Lutherse Kerk) iets anders is as die sondige begeerte na die nalaste se ander besittings.

Die verdeling van die tiende gebod is verder onaanvaarbaar omdat 'n sondige begeerte sondig is ongeag die voorwerp waarop dit gerig is. Bowendien word die gebod oor die sondige begeerte in die Nuwe Testament slegs as een gebod gesien, want twee maal word dit aangehaal bloot as: "Jy mag nie begeer nie" (Rom. 7:7; 13:9) sonder vermelding van enige voorwerp van die begeerte (De Bruyn, 1976:79). So is dit ook deur die IIK beskou en verklaar.

\subsection{Die afwysing van biblisisme}

Dat die opstellers van die HK in hulle verklaring van die Tien Gebooie afwysend gestaan het teenoor die biblisisme, kan veral in die verklaring van die derde gebod gesien word.

Een van die kenmerkende eienskappe van die biblisiste is dat hulle 'n besonder groot waarde aan sekere Skrifuitsprake heg, sonder om dit in die lig van die Bybel as geheel 
te beskou (Velema, 1990:79). Die Wederdopers wat baie aktief was in die tyd toe die HK opgestel is, was sulke biblisiste. Daarom het hulle op grond van Matteus 5:33-37 afwysend gestaan teenoor alle vorms van eedswering sonder om ander uitsprake in die Skrif oor die eed in berekening te bring. (Vgl. Strauss, 1988:137; Van Zuijlekom, 1970:402.)

Uit die HK se verklaring van die derde gebod, waarin onder andere gehandel word oor die aflegging van die eed (vr. en antw. 101), is dit duidelik dat die biblisistiese siening van die Wederdopers vir die opstellers onaanvaarbaar was. Dat dit onaanvaarbaar was, blyk uit die feit dat terwyl die Wederdopers op grond van Matteus 5:33-37 eedswering radikaal afgewys het, in antwoord 101 op grond van die getuienis van die hele Bybel en nie net van 'n enkele teks nie, verklaar word dat 'n mens wel 'n eed mag sweer as dit tot eer van God en tot heil van die naaste gedoen word.

\subsection{Die afwysing van perfeksionisme (die eskatologiese perspekticf)}

In die verklaring van die tiende gebod word gesê dat "selfs die geringste begeerte of gedagte teen enige gebod van God nooit in ons hart mag opkom nie" (antw. 113). In antwoord op die vraag of die bekeerdes daartoe in staat is, kom die realisme van die gereformeerde belyer duidelik tot openbaring (Strauss, 1988:138) in die erkenning dat "selfs die allerheiligstes, solank hulle in hierdie lewe is, nog maar 'n geringe begin van hierdie gehoorsaamheid het" (antw. 114). "Daarmee is die Doperse perfeksionisme duidelik afgewys" (Strauss, 1988:138).

Dit beteken egter nie dat die gelowige in die ander uiterste moet beland en in 'n soort 'imperfeksionisme' moet berus nie. Juis die streng wetsprediking het by die Christen die uitwerking dat hy sy "sondige natuur hoe langer hoe beter kan leer ken en met groter verlange na die vergewing van sondes en na die geregtigheid in Christus soek" (antw. 115). So 'n Christen het deur die genade van die Heilige Gees noodwendig "'n ernstige voorneme om nie alleen volgens sommige nie maar volgens al die gebooie van God te lewe" (antww. 114,115).

Daarby word daar aan die onderhouding van die gebooie 'n duidelike eskatologiese perspektief gegee: volmaaktheid sal in hierdie lewe nooit bereik word nie, maar na hierdie lewe wel. Dit is die uitsig én troos van die gelowige. 


\section{SAMEVATTING}

Uit bogenoemde uiteensetting van die kenmerke van die Tien Gebooie volgens die verklaring van die $\mathrm{HK}$ het dit duidelik geword dat dit so verklaar is dat die ware bedoeling daarvan in die lig van die hele Skrif weergegee word. Daarom is die Tien Gebooie, soos dit in die HK verklaar is, van fundamentele betekenis vir die gereformeerde teologiese etiek. Wie die Tien Gebooie ken en uitlewe op die wyse wat dit in die IK aangedui word, het inderdaad die egte Christelike "lewenskunde en lewenskuns" gevind (Engelbrecht, 1989:639).

\section{BIBIIOCRAFIE}

ABMA, H.(i. 1980? Tien woorden elhick. Kampen : Kok.

BOUMA, C. 1950. Hel Evangelic naar Johannes II; 3dc Jruk. Korte Verklaring der Heilige Schrift. Kimpin : Kok.

BÜSSER, F, 1963. Dic Bedeulung des Gesclzes. (In Coenen, L. Handbuch zum Heidelberger Katcichismus. Neukirchen-Vluyn : Neukirchener Verlag. p. 159-170.)

BUYS, P.W. 1976. Dic botsing van pligtc as cticse vraagstuk. Potchefstroom : PU vir CHO.

BUYS, P.W. 1989. Etick. Potchefstroom : PU vir CHO (D266/88).

CALVYN, J. 1986. Institusic van die Christelike godsdiens - 2. Uit Lalyn vertaal deur H.W. Simpson. Potchefstroom : Calvyn Jubileum Bockcfonds.

DE BRUYN, P.J. 1973. Aktiewe kerkgangers. Potchefstroom : Pro Rege.

DE BRUYN, P.J. 1976. God se ticn bakens vir dic lewe van die mens: oor die Tien Gebooie. Polchefstroom : Pro Rege.

DE GRAAF, S.G. 1954. Hel ware geloof: beschouwingen over Zondag 1 - 22 van de Heidelbergse Calcchismus. Kampen : Kok.

DOUMA, J. 1985. De Tien Cicboden I. Kampen : Van den Berg.

DOUMA, J. 1987. De Ticn (jeboden III. Kampen : Van den Berg.

ENGELBREC.ITT, B.J. 1989. 'n Vergelyking tussen dic teolugie van die Nederlandse (jeloofsbelydenis en dic Heidelbergse Kalcgismus. Henonnde Teologiese Studies, 45(3):626-641, Sept.

FLETCHER, J. 1\%7. Moral responsibility: situation ethics at work. London : SCM Press.

GEESINK, W. 1931. (icreformecrde ethick I. Kampen : Kok.

GERERORMEERDE KERKEN NEDERLAND, 1981. God mel ons: over de aard van hel Schrifige\%ag. Leusden : Kerkinformatic.

GREIJDANUS, S. 1955. Het evangelic nalar Lucas - I. Korte Verklaring der Heilige Schrift. Kampen : Kok.

HAITJEMA, Th. L. 1\%2. De Heidelbergse Catechismus als klankbodem en inhoud van het acluele belijden onatr kesk. Wageningen : Veenman.

HOLWERDA. B. 1955. De dingen die ons van God geschonken zijn III. Goes: Oosterbaan \& Le Cointre.

KROEZE, J.H. 1970. Bybel en seks. Braamfonlcin (Johannesburg) : De Jong.

KUITERT. H.M. 1970. Anders gezegd: ecn verzameling theologische opstellen voor de welwillende lewer. Kampen : Kok.

NAGMAALSFORMULIER. 1988. Formulier vir dic vicring van die heilige nagmaal. (In Dic berymde Psalms en Skriberymings. Polchefstroom : Administraticwe Buro van die Gereformecrde Kerke, p. 617-626.) 
OVERDUIN, J. 1961. Wat hebben wij tot Rome te zeggen? Kampen : Kok.

PRETORIUS, H. 19\%0. Om gay te wees: sıraf of seën? Pretoria : Homofilos SA Uitgewers.

PRONK, P. 1989. Tegennatuurlijk? Typen van morele argumentatie inzake homosexualiteit. Amsterdam : VU Boekhandel.

SCHULZE, L.F. 1991. Ons glo met die hart. Potchefstroom : L.F. Schulze.

STRAUSS, S.A. 1988. Riglyne vir die etick vanuit dic Drie Formuliere van Eenheid. (In De Bruyn, PJ. red. Waar die paaie saamwoon. Potchefstroom: Potchefstroomse Tcologicse Publikasies. p. 131-145.)

URSINUS, Z. 1886. Verklaring op den Heidelbergschen Catechismus II. Uit Latyn vertaal deur C. van Proosdij. Kampen : Zalsman.

VAN ANDEL, H.A. 1935. De ecnige troost: precken over den Heidelbergschen Catechismus. Franeker : Wever.

VAN DEN BERG, J. 1967? De wetsprediking in historisch perspectief. (In Van den Berg, J. et al. De Thora in de Thora I. Aatten : De (iratitschap. p. 30-49.)

VAN MINNEN. I'K67? Opschrift. (In Van den Berg, J. et al. De Thora in de Thora 1. Aalien : De Graafschap. p. 50-52.)

VAN ZUIJLEKOM, B. 1970. De ecd, dic trouw en waarheid bevestigt. (In Bocrsma, T. \& Francke, J. reds. De hoofdsom van hel evangclic: Catcchismusprcken. Enschede : Bocrsma. p. 401-410.)

VELDKAMP, H. 1955? Zondagskinderen: kantlekeningen bij de Heidelbergse Catechismus II. Francker : Wever.

VELEMA, W.H. 1990. Oriëntatie in de Christclijke ethick. 's-Gravenhage : Boekencentrum.

WIELEN(jA, B. 1947. Onze Catechismus II. Kampen : Kok. 